\title{
Child sexual abuse presenting to a teaching hospital in Colombo, Sri Lanka
}

\author{
*Yasodha Maheshi Rohanachandra ${ }^{1}$, Irosha Amarabandu', Prasanna Dassanayake²
}

Sri Lanka Journal of Child Health, 2021; 50(4): 650-654

DOI: http://doi.org/10.4038/sljch.v50i4.9856

\begin{abstract}
Introduction: Prevalence of child sexual abuse in Sri Lanka ranges between $14 \%-44 \%$ with rates of sexual harassment as high as $78.5 \%$. Hospital based studies done in Sri Lanka have shown a wide variation in the number presenting to hospitals with child sexual abuse. Child sexual abuse is associated with a wide range of psychosocial adversities.
\end{abstract}

Objectives: To identify the victim/perpetrator characteristics, risk factors, pattern of disclosure and psychological consequences of child sexual abuse presenting to a Teaching Hospital in Sri Lanka.

Method: This was a retrospective case review study of victims who presented to a Teaching Hospital in Sri Lanka with sexual abuse between 2015 and 2019.

Results: During the study period 164 children presented with sexual abuse. Females comprised $82.9 \%$ and $67.1 \%$ were older than 12 years. Majority $(73.6 \%)$ had penetrative abuse. Multiple incidents of abuse occurred in $58.5 \%$. Of the perpetrators, $94.5 \%$ were known to the child. Only $42.7 \%$ revealed about the incident within the first week. Delayed disclosure was higher in penetrative abuse $(p<0.01)$, multiple incidents of abuse $(\mathrm{p}<0.01)$ and abuse by a known person $(\mathrm{p}<0.05)$. Psychological sequelae were seen in $28.7 \%$ and were higher in those who delayed disclosure $(\mathrm{p}<0.05)$ and in those who did not disclose spontaneously $(\mathrm{p}<0.01)$.

Conclusions: In this study, rate of sexual abuse was $82.9 \%$ in females and $67.1 \%$ in those older than 12 years. Of the perpetrators, $94.5 \%$ were known to the child. Delayed disclosure was significantly higher in penetrative abuse $(p<0.01)$,

\footnotetext{
${ }^{1}$ University of Sri Jayewardenepura, Sri Lanka, ${ }^{2}$ Colombo South Teaching Hospital, Sri Lanka *Correspondence: yasodha@sjp.ac.lk
}

D https://orcid.org/ 0000-0002-3671-7674 (Received on 21 October 2020: Accepted after revision on 18 December 2020)

The authors declare that there are no conflicts of interest.

Personal funding was used for the project.

Open Access Article published under the Creative

Commons Attribution CC-BY@C (i) License multiple incidents of abuse $(\mathrm{p}<0.01)$ and abuse by a known person $(\mathrm{p}<0.05)$. Psychological sequelae were seen in $28.7 \%$

(Key words: Child abuse, Sexual abuse, Child sexual abuse, Sri Lanka)

\section{Introduction}

Child sexual abuse (CSA) is a major public health problem worldwide. Globally, $7.9 \%$ of males and $19.7 \%$ of females are sexually abused before 18 years ${ }^{1}$. CSA alone accounts for about $1 \%$ of the global burden of disease ${ }^{2}$. An average of 1297 complaints related to CSA per year has been received by the National Child Protection Authority (NCPA) from 2015 to 2019, the majority of complaints being related to sexual harassment ${ }^{3}$. An average of 1593 complaints related to CSA per year has been received by the police over the same period, the majority of these complaints being related to statutory rape ${ }^{4}$.

Prevalence of CSA in Sri Lanka ranges between $14 \%-44 \%$ with rates of sexual harassment as high as $78.5 \% 0^{5-7}$. A higher prevalence has been reported in Northern Sri Lanka, an area which has been affected by the civil war ${ }^{8}$ and in areas associated with the tourism industry ${ }^{9}$. Hospital based studies have shown a wide variation in the number presenting to hospitals with alleged abuse, with numbers ranging from 84 cases over 15 years (average $5.6 /$ year) ${ }^{10}$ to 183 over 18 months (average $122 /$ year) $^{11}$. Although CSA is prevalent in Sri Lanka, studies examining victim and perpetrator characteristics, risk factors for abuse, pattern of disclosure and psychological impact of abuse are limited in Sri Lanka. Identifying the victim/perpetrator characteristics, risk factors and impact of CSA is vital in designing interventions to this vulnerable population.

\section{Objectives}

This study aimed to assess the victim and perpetrator characteristics, risk factors, pattern of disclosure and psychological impact of CSA in children presenting to a Teaching Hospital in Colombo, Sri Lanka.

\section{Method}

This was a retrospective case review study done in Colombo South Teaching Hospital, Sri Lanka. The study included all children and adolescents (under 
16 years) referred to the Judicial Medical Officer of the hospital, due to alleged sexual abuse from 2015-2019.

A specifically designed data extraction form was used to retrieve data from patient's paper-based medico-legal records. This form consisted of sociodemographic details, risk factors for abuse (parent's age and educational status, single parent families, parental substance use, parental mental illness, living circumstances, lack of supervision, whether schooling), perpetrator characteristics, type of abuse and pattern of disclosure. Child's clinical diagnosis recorded by the Consultant Psychiatrist according to the DSM-V criteria was also obtained from records. Parents' age and educational status, parental substance use and parental mental illness were not found in most records. Therefore, these variables were removed.

\section{Ethical issues}

Ethical clearance was obtained from the Ethics Review Committee of the University of Sri Jayewardenepura (No. FMS/USJP ERC 60/19). Permission was obtained from the Director of the particular Teaching Hospital to access the records. Being a retrospective study, informed consent was not a possibility.

\section{Statistical analysis}

Chi square test was used to analyse associations between categorical variables.

\section{Results}

Over the 5 year period from January 2015December 2019, 164 children and adolescents presented to the Judicial Medical Officer (JMO) for assessment following alleged sexual abuse. Majority $(82.9 \%, \mathrm{n}=136)$ of the victims were female and $67.1 \%$ were older than 12 years. Only $49.4 \%$ were living with both parents. Of the children, $18.3 \%$ were not attending school (Table 1). A significantly higher number of females were not attending school compared to males $(p<0.05)$.

Perpetrators were male in $99.9 \%(n=163)$ of the cases. In $31.1 \%$ of instances, the child had been threatened and in $15.2 \%$ of the cases the child had been given a reward such as a toy or food. Females were significantly more likely to be abused at home than males $(p<0.05)$. Characteristics of the abuse, the perpetrator and patterns of disclosure are displayed in Table 2.

Table 1: Socio-demographic details

\begin{tabular}{|l|c|c|c|}
\hline \multicolumn{1}{|c|}{ Socio-demographic factor } & Female & Male & Total \\
\cline { 2 - 3 } \multicolumn{1}{l|}{ Age } & Number (\%) & Number (\%) & \\
$<5$ years & $06(03.7)$ & $0(0)$ & $06(03.7)$ \\
$5-12$ years & $32(19.5)$ & $16(09.8)$ & $48(29.3)$ \\
$>12$ years & $98(59.9)$ & $12(07.2)$ & $110(67.1)$ \\
\hline Parents' marital status & & & \\
Married & $84(51.2)$ & $21(12.8)$ & $105(64.0)$ \\
Separated & $19(11.6)$ & $03(01.8)$ & $22(13.4)$ \\
Widowed & $13(07.9)$ & $03(01.8)$ & $16(09.8)$ \\
Divorced & $18(10.9)$ & $01(0.6)$ & $19(11.7)$ \\
Single & $01(0.6)$ & $0(0)$ & $01(0.6)$ \\
\hline Living circumstances & $65(39.6)$ & $16(09.8)$ & $81(49.4)$ \\
Living with both parents & $29(17.7)$ & $05(03.0)$ & $34(20.7)$ \\
Living with single parent & $26(15.9)$ & $01(0.6)$ & $27(16.5)$ \\
Living with relatives (without parents) & $16(09.8)$ & $06(03.6)$ & $22(13.4)$ \\
In out of home care & $107(65.2)$ & $27(16.5)$ & $134(81.7)$ \\
\hline Schooling & $29(17.7)$ & $01(0.6)$ & $30(18.3)$ \\
Attending school & & & \\
Not attending school & & & \\
\hline
\end{tabular}


Table 2: Characteristics of the abuse, the perpetrator and patterns of disclosure

\begin{tabular}{|c|c|c|c|}
\hline \multirow[t]{2}{*}{ Characteristic } & Female & Male & \multirow[t]{2}{*}{ Total } \\
\hline & Number (\%) & Number (\%) & \\
\hline $\begin{array}{l}\text { Type of abuse } \\
\text { Vaginal penetrative } \\
\text { Anal penetrative } \\
\text { Oral penetrative } \\
\text { Digital penetrative } \\
\text { Non penetrative }\end{array}$ & $\begin{array}{l}75(45.7) \\
07(04.3) \\
10(06.1) \\
10(06.1) \\
34(20.7)\end{array}$ & $\begin{array}{c}0(0) \\
16(09.7) \\
02(01.2) \\
01(0.6) \\
09(05.5)\end{array}$ & $\begin{array}{l}75(45.7) \\
23(14.0) \\
12(07.3) \\
11(06.7) \\
43(26.2)\end{array}$ \\
\hline $\begin{array}{l}\text { Number of incidents } \\
\text { Single } \\
\text { Multiple }\end{array}$ & $\begin{array}{l}59(36.0) \\
77(47.0)\end{array}$ & $\begin{array}{l}09(05.4) \\
19(11.6)\end{array}$ & $\begin{array}{l}68(41.4) \\
96(58.6)\end{array}$ \\
\hline $\begin{array}{l}\text { Place of abuse } \\
\text { Home } \\
\text { Outside home } \\
\text { Missing }\end{array}$ & $\begin{array}{l}63(38.4) \\
72(43.9)\end{array}$ & $\begin{array}{l}07(04.3) \\
21(11.6)\end{array}$ & $\begin{array}{c}70(42.7) \\
93(56.7) \\
01(0.6)\end{array}$ \\
\hline $\begin{array}{l}\text { Perpetrator } \\
\text { Known } \\
\text { Unknown }\end{array}$ & $\begin{array}{c}128(78.0) \\
08(04.9)\end{array}$ & $\begin{array}{c}27(16.5) \\
01(0.6)\end{array}$ & $\begin{array}{c}155(94.5) \\
09(05.5)\end{array}$ \\
\hline $\begin{array}{l}\text { Physical evidence } \\
\text { Present } \\
\text { Absent }\end{array}$ & $\begin{array}{l}67(40.9) \\
69(42.1) \\
\end{array}$ & $\begin{array}{l}11(06.7) \\
17(10.4) \\
\end{array}$ & $\begin{array}{l}78(47.6) \\
86(52.4) \\
\end{array}$ \\
\hline $\begin{array}{l}\text { Disclosure } \\
\text { Within } 1 \text { week } \\
\text { After 1 week } \\
\end{array}$ & $\begin{array}{l}57(34.8) \\
79(48.2) \\
\end{array}$ & $\begin{array}{l}13(07.9) \\
15(09.1) \\
\end{array}$ & $\begin{array}{l}70(42.7) \\
94(57.3) \\
\end{array}$ \\
\hline $\begin{array}{l}\text { Spontaneous disclosure } \\
\text { Yes } \\
\text { No } \\
\text { Missing }\end{array}$ & $\begin{array}{l}87(53.0) \\
48(29.2)\end{array}$ & $\begin{array}{l}15(09.1) \\
13(07.9)\end{array}$ & $\begin{array}{c}102(62.2) \\
61(37.2) \\
01(0.6) \\
\end{array}$ \\
\hline $\begin{array}{l}\text { Psychological consequences } \\
\text { Present } \\
\text { Absent }\end{array}$ & $\begin{array}{l}37(22.6) \\
99(60.3)\end{array}$ & $\begin{array}{l}10(06.1) \\
18(11.0) \\
\end{array}$ & $\begin{array}{c}47(28.6) \\
117(71.3) \\
\end{array}$ \\
\hline
\end{tabular}

The time taken for disclosure ranged from immediately after the incident to more than a year. Majority of the children had revealed about the incident to the mother $(40.9 \%)$, followed by the grandmother $(13.4 \%)$ and sister $(9.1 \%)$. Delayed disclosure (i.e. after 1 week) was significantly higher in children who suffered penetrative abuse $(p<0.01)$, those who had multiple incidents of abuse $(p<0.01)$ and where the abuse was perpetrated by a known person $(p<0.05)$. Spontaneous disclosure was significantly lower in children who disclosed about the incident after more than 1 week $(\mathrm{p}<0.01)$.

Psychological consequences were seen in $28.7 \%$ $(\mathrm{n}=47)$ of the children, with depression being the commonest $(8.5 \%)$, followed by adjustment disorder $(7.3 \%)$ and acute stress reaction $(6.7 \%)$. Psychological consequences were significantly higher in victims who had physical evidence of abuse $(p<0.01)$, delayed (after 1 week) disclosure of the incident $(p<0.05)$ and in children who did not disclose the abuse spontaneously $(\mathrm{p}<0.01)$.

\section{Discussion}

In the present study, 164 children and adolescents presented with alleged CSA during a 5 year period.
This is much higher than two case review studies previously carried out in Teaching Hospitals in Colombo. In one study, only 35 children presented within a 5 year period from 2010-2015 ${ }^{12}$. In another study, 78 children and adolescents presented over a 3 year period from 2011-2013 ${ }^{13}$. These findings may be due to an increase in the prevalence of CSA or may reflect increased public awareness of CSA. However, the number of cases who presented in our study is much less than that of Northern (352 cases over a 6 year period) and North Western (183 cases over 18 months) areas of the country ${ }^{11,14,15}$. Further studies should be done to identify reasons for variation of the rates of CSA in different parts of the country.

Consistent with world literature, in the present study, the majority of the victims were female and older than 12 years ${ }^{16-18}$. The absence of one or both parents has also been described as a risk factor for CSA in previous studies, which is in keeping with our study. In our study only $49.4 \%$ of children lived with both parents, in contrast to $78 \%$ in National Sri Lankan figures ${ }^{19}$. In addition, in our study only $81.9 \%$ of children were attending school in contrast to $90.1 \%$ in national figures ${ }^{19}$. This may suggest that in accordance with previous studies, 
not attending school may also be a risk factor for CSA in Sri Lanka ${ }^{14,15,20}$. In keeping with world literature, our study also found that most perpetrators are male and known to the child. In the present study, a significantly higher number of females were not attending school compared to males. Gender inequality within the education system may be a possible explanation but this needs to be further studied.

Our study showed a delay in reporting of CSA and that disclosure is prompted by questions from caregivers, which is in keeping with the world literature ${ }^{21}$. Most studies have found that children commonly disclosed to their parents or their peers. However, in the present study, most children disclosed to the mother followed by the grandmother. Disclosure to the father was very low (3.7\%). In Sri Lankan culture, extended family plays a greater role in a child's life and grandmothers often care for the children in mothers' absence. This may be the reason for disclosure to grandmother to be more common in Sri Lanka. Being abused by a known person, being abused on multiple occasions and penetrative abuse were associated with delayed disclosure in our study, which is consistent with previous findings.

Studies done in Sri Lanka show that $16 \%-68 \%$ of children have a psychological impact following abuse $\mathrm{e}^{10,12}$, which is consistent with our findings. The most commonly reported psychological consequences in these studies were depressive disorder, adjustment disorder and post-traumatic stress disorder (PTSD). The present study also revealed depression and adjustment disorder to be the common psychological sequelae following CSA, followed by acute stress reaction. However, there were no children diagnosed to have PTSD. This is possibly due to the differences in the time of presentation of the victims in these studies.

As this was a file review study, some of the important variables that were not recorded needed to be excluded (e.g. parents age and educational status, parental substance use and parental mental illness) and this may have influenced the results, which is a limitation of our study.

Delayed disclosure is common and is associated with a higher psychological impact. As disclosure of abuse is often delayed and often follows direct questioning, parents should be aware of the signs suggesting possible sexual abuse, so that the children can be referred for services in a timely manner. Given the wide variety in the numbers of children and adolescents presenting with alleged abuse within different regions of the country, there is a need for nationwide studies to assess the prevalence of the problem across Sri Lanka.

\section{Conclusions}

In this study the rate of sexual abuse was $82.9 \%$ in females and $67.1 \%$ in those older than 12 years. Of the perpetrators, $94.5 \%$ were known to the child. Delayed disclosure was significantly higher in penetrative abuse $(\mathrm{p}<0.01)$, multiple incidents of abuse $(\mathrm{p}<0.01)$ and abuse by a known person $(p<0.05)$. Psychological sequelae were seen in $28.7 \%$

\section{References}

1. Wihbey J. Global prevalence of child sexual abuse. Journalist Resource [Last on Aug and Updated on 2011 Nov 15] Available from: Journalists resource org/studies//global-prevalence-childsexual-abuse. 2011.

2. Bassani DG, Palazzo LS, Béria JU, Gigante LP, Figueiredo AC, Aerts DR, et al. Child sexual abuse in southern Brazil and associated factors: a population-based study. BMC Public Health 2009; 9(1): 133.

https://doi.org/10.1186/1471-2458-9-133

PMid: 19432975 PMCid: PMC2685133

3. National Child Protection Authority, Sri Lanka. Accessed on 01/10/2020 from: www.childprotection.org.lk

4. Department of Police, Sri Lanka. Accessed through www.police.lk on 01.10 .2020

5. Abeywardene A, Atukorale S, Abeynayaka K, Athauda T. A study on knowledge and prevalence of sexual harassment and abuse among schoolboys in Colombo District. Sri Lanka Journal of Child Health 2004; 33: 9-17. https://doi.org/10.4038/sljch.v33i1.661

6. Fernando A, Karunasekera W. Juvenile victimisation in a group of young Sri Lankan adults. Ceylon Medical Journal 2009; 54(3): 80-4. https://doi.org/10.4038/cmj.v54i3.1200 PMid: 19999787

7. Perera B, Østbye T. Prevalence and correlates of sexual abuse reported by late adolescent school children in Sri Lanka. International Journal of Adolescent Medicine and Health 2009; 21(2): 203-11. https://doi.org/10.1515/IJAMH.2009.21.2. 203

PMid: 19702200 
8. Somasundaram D. Short-and long-term effects on the victims of terror in Sri Lanka. Journal of Aggression, Maltreatment \& Trauma 2005; 9(1-2): 215-28. https://doi.org/10.1300/J146v09n01_26

9. de Silva DH. Some reflections on child abuse in Sri Lanka. Sri Lanka Journal of Child Health 2000; 29(4): 104-6.

https://doi.org/10.4038/sljch.v29i4.746

10. Ginige $\mathrm{P}$, Tennakoon S, Perera F, Baminiwatta A. Characteristics of children who have been sexually abused, incidents of abuse and perpetrators; a study from of a tertiary care clinic sample in central Sri Lanka. Sri Lanka Journal of Medicine 2018; 27(2): 22-30.

https://doi.org/10.4038/sljm.v27i2.64

11. Amararatne RRGS, Vidanapathirana M. Child sexual abuse in Puttalam, Sri Lanka: a medico-legal analysis. Medico-Legal Journal of Sri Lanka 2016; 4(2): 34. https://doi.org/10.4038/mljsl.v4i2.7336

12. Rohanachandra Y, Dahanayake D, Pathigoda P, Wijetunge G. Characteristics of victims of alleged child sexual abuse referred to a child guidance clinic of a children's hospital. Ceylon Medical Journal 2015; 60: 163-4.

https://doi.org/10.4038/cmj.v60i4.8227

PMid: 26778400

13. Vidanapathirana M. Child sexual abuse; a medico-legal analysis. International Journal of Medical Toxicology and Forensic Medicine 2014; 4(3): 91-7.

14. Chandrasiri M, Wijewardena D, Lanerolle S, Chandrasiri S, Wijewardena K, Cooray R. Child sexual abuse presenting to district general hospital, Chilaw. Ceylon Medical Journal 2017; 62(1): 29-33. https://doi.org/10.4038/cmj.v62i1.8430 PMid: 28390329

15. Sathiadas M, Mayoorathy S, Varuni K, Ranganathan SS. Child abuse in northern Sri Lanka. The Indian Journal of Pediatrics 2017; 84(2):128-33. https://doi.org/10.1007/s12098-016-21930

PMid: 27431383
16. Aydin B, Akbas S, Turla A, Dundar C, Yuce M, Karabekiroglu K. Child sexual abuse in Turkey: an analysis of 1002 cases. Journal of Forensic Sciences 2015; 60(1): 61-5.

https://doi.org/10.1111/1556-4029.12566

PMid: 25066376

17. Kloppen K, Haugland S, Svedin CG, Mæhle M, Breivik K. Prevalence of child sexual abuse in the Nordic countries: A literature review. Journal of Child Sexual Abuse 2016; 25(1): 37-55. https://doi.org/10.1080/10538712.2015.11 08944

PMid: 26809050

18. Yiming C, Fung D. Child sexual abuse in Singapore with special reference to medico-legal implications: A review of 38 cases. Medicine, Science and the Law 2003; 43(3): 260-6.

https://doi.org/10.1258/rsmmsl.43.3.260

PMid: 12899433

19. Sri Lanka - Global School-based Student, Health Survey 2016. Ministry of Health, Sri Lanka. ISBN: 978-955-3666-00-0. (https://nada.searo.who.int/index.php/catal og/8).

20. Meinck F, Cluver LD, Boyes ME. Longitudinal predictors of child sexual abuse in a large community-based sample of South African youth. Journal of Interpersonal Violence 2017; 32(18): 2804-36. https://doi.org/10.1177/088626051559633 1

PMid: 26224720

21. Hershkowitz I, Lanes O, Lamb ME. Exploring the disclosure of child sexual abuse with alleged victims and their parents. Child Abuse and Neglect 2007; 31(2):111-23. https://doi.org/10.1016/j.chiabu.2006.09.0 04

PMid: 17316793 